\title{
Impact of Rice Tariffication Law in selected Rice Farmers in Nueva Ecija, Philippines
}

\author{
Mae Flor Vertudes, Christopher Dave Musa, Mary Ann Cosilet, Rommel
}

\author{
Salagubang, Felipe Balaria
}

\begin{abstract}
This paper discussed the impact of rice tariffication law in selected farmers in a certain barangay in Nueva Ecija, Philippines. The descriptive method of research was utilized and the questionnaire served as the instrument for collecting data.

Findings showed that the initial impact of the law that had already experienced by the selected farmers was the declining farm gate prices of "palay". This situation affected their income and livelihood. Despite this problem, most of the farmers responded that they would continue in rice farming because this is the only way they know how to earn a living. As initial support from the government, most of the respondents received free certified inbred seeds and availed rice credit assistance with minimal interest rates. Additionally, they were given trainings to enhance their skills and knowledge of rice production.
\end{abstract}

Keywords-Agriculture, rice farmers, rice production and rice tarrification law.

\section{INTRODUCTION}

Tariffs and quantitative restrictions (QRs) are two policy instruments used in dealing with the international trade of goods. Tariffs are the taxes imposed by the government on both imported and exported products, while quantitative restrictions (QRs) are measures such as quotas, bans, and licensing requirements imposed by the government to limit the volume of a particular commodity that enters the country [1].

The Philippines acceded to the World Trade Organization (WTO) in 1995. Under the agreement on agriculture, QRs and other protective measures that may distort free trade will be removed and replaced by reduced tariff rates. Rice was, however, exempted from the removal of QR because of food security issues [2]. The Philippine requested QR on rice imports until 2005 but was extended until 2012 and then extended again until June 30, 2017. For several years, the government has adhered to rice QRs in protecting the local rice industry and to prepare the local farmers to become competitive in the world market.

As trade liberalization is being pushed through, the
Philippine rice industry bears the impact of global competition. Liberalizing trade means loosening the restrictive measures to a certain degree to ease the flow of goods and services in and out of the country [3]. After 24 years since the membership of the Philippines with WTO, QRs on rice imports have finally been lifted through the passage ofRA 11203 (An Act Liberalizing the Importation, Exportation and Trading of Rice, Lifting for the Purpose the Quantitative Import Restriction on Rice, and for Other Purpose) also known as the Philippine Rice Tariffication Law which took effect on March 5, 2019. The law essentially allows for the liberalization of rice imports. This removes the previously placed quota and replaced with higher tariffs on rice imports, permitting traders to import a near-unlimited quantity of rice [4]. The new law provides the following tariff rates: $35 \%$ for rice imports originating from Association of Southeast Asian Nations (ASEAN) member states; $40 \%$ for rice imports originating from non-ASEAN countries and within the minimum access volume (MAV) of 350,000 metric tons; $180 \%$ for rice imports originating from non-ASEAN countries and above the MAV [5]. 
The law provides safety net measures for local farmers underthe Rice Competitiveness Enhancement Fund (RCEF) which is expected to help and support the rice farmers to cope up with the liberalization of the rice market. The government will allocate P10 billion annually for the next six years to support the Filipino rice farmers and this will be assessed after the first three years of its implementation. The P10-BRCEF will be allocated and disbursed as follows: $50 \%$ for rice farm types of machinery and equipment, $30 \%$ for rice seed development, propagation and promotion, $10 \%$ for expanded rice credit assistance and $10 \%$ for rice extension services. The law provided furthermore that tariff revenues in excess of the P10 billion will be earmarked for the following: rice farmer financial assistance, titling of agricultural rice lands, expanded crop insurance program on rice and crop diversification program. In addition, the NFA will buy rice exclusively from local farmers for its buffer stocking mandate for emergencies and disaster relief [5].

Even though the government gives assurance that proper implementation and measures will be put in place, rice farmers are still concerned that tariffication law would hurt them and the local rice industry in the long term. The objective of this study is to determine and analyze the impact of rice tariffication law on selected rice farmers in Nueva Ecija, Philippines.

\section{MATERIALS AND METHODS}

The study utilized the descriptive method of research and used the quotasampling technique in selecting respondents in a certain barangay in Nueva Ecija, Philippines. Based on the 2018 socio-economic profile of the Brgy, 515 households are engaged in rice farming. The researchers selected $10 \%$ of the total population as sample size which consists of 52 respondents. The data were collected using structured questionnaires and were analyzed and interpreted using statistical tools such as frequency and percentage. The study also utilized secondary data from the Philippine Statistics Authority (PSA).

\section{RESULTS AND DISCUSSION}

\section{A. Profile of the respondents}

Based on the gathered data, $81 \%$ of the respondents are male, $52 \%$ belong to ages more than 50 years old, $40 \%$ are elementary graduates, $38 \%$ are with the farming experience of $31-40$ years, $60 \%$ belong to a household with 1-5 members, $58 \%$ are with farm areas of 1-3.99 hectares, $35 \%$ are marginal farmers with farm area below 1 hectare and source of farmland were mostly inherited (42\%) and rented $(42 \%)$.

In addition, $69 \%$ is currently a member of eligible farmer association or registered rice cooperative and 94\% are currently enlisted to Registry System for Basic Sectors in Agriculture (RSBSA) which are requirements to become eligible farmer-beneficiaries and to access RCEF programs.

\section{B. Awareness of the Respondents}

Table 1. Awareness of the Respondents in the Rice Tarrification Law

\begin{tabular}{|c|c|c|c|c|c|c|c|}
\hline \multirow{2}{*}{\multicolumn{2}{|c|}{ Particulars }} & \multicolumn{2}{|c|}{ Frequency } & \multicolumn{2}{|c|}{ Percentage } & \multirow{2}{*}{\multicolumn{2}{|c|}{ Total }} \\
\hline & & Yes & $\mathrm{No}$ & Yes & $\mathrm{No}$ & & \\
\hline 1 & Are you familiar with Rice Tariffication Law? & 42 & 10 & $81 \%$ & $19 \%$ & 52 & $100 \%$ \\
\hline 2 & $\begin{array}{l}\text { Are you well-informed about the law and how it will be } \\
\text { implemented? }\end{array}$ & 16 & 36 & $31 \%$ & $69 \%$ & 52 & $100 \%$ \\
\hline 3 & Are you in favor of Rice Tariffication Law? & 0 & 52 & $0 \%$ & $100 \%$ & 52 & $100 \%$ \\
\hline 4 & $\begin{array}{l}\text { Do you think the assigned government agencies can } \\
\text { effectively and efficiently implement the RCEF programs? }\end{array}$ & 33 & 19 & $63 \%$ & $37 \%$ & 52 & $100 \%$ \\
\hline 5 & $\begin{array}{l}\text { Do you think the RCEF programs will really help you to } \\
\text { improve your yield and income? }\end{array}$ & 32 & 20 & $62 \%$ & $38 \%$ & 52 & $100 \%$ \\
\hline 6 & $\begin{array}{l}\text { Do you think we can really compete with cheap rice } \\
\text { imports? }\end{array}$ & 19 & 33 & $37 \%$ & $63 \%$ & 52 & $100 \%$ \\
\hline
\end{tabular}


Table 1 presents the awareness and perception of the respondents about RTL. Based on the gathered data, $81 \%$ of the respondents are familiar with the newly enacted law but $69 \%$ said that they have little knowledge about the law and how its implementation. According to them, they are not well-informed about the law and they only heard some information from other farmers and news from Television and social media sides.

All farmers responded that they were not in favor of the newly enacted law. Because they believed that it is the main reason for declining palay prices.

Meanwhile, $63 \%$ of the respondents agreed that the government agencies are effective and efficient in implementing RCEF programs and $62 \%$ of respondents are believing and hoping that RCEF programs will help to increase their yield and income.

On the other hand, $63 \%$ of the respondents believed that it would be hard for them to compete with the cheaper price of imported rice and they also believed that it will take time before they can cope up with the liberalized rice market. Imported rice is cheaper than domestically produced rice. The reason behind this price gap is because the palay production in the Philippines is costlier as compared to the major rice exporting countries such as Vietnam and Thailand. For instance, palay production in the Philippines costs 90 percent higher than in Vietnam. The Philippines produces palay at Php. 12.41 per $\mathrm{kg}$ and milled rice at Php. 19.24 per kg, while Viet Nam's cost is only Php. 6.53 per kg and Php. 9.92 per kg respectively [6].

\section{Impact of RTL}

Table 2. Impact of Rice Tariffication Law to the Farmers

\begin{tabular}{|c|c|c|c|c|c|c|c|}
\hline \multirow{2}{*}{\multicolumn{2}{|c|}{ Particulars }} & \multicolumn{2}{|c|}{ Frequency } & \multicolumn{2}{|c|}{ Percentage } & \multirow{2}{*}{\multicolumn{2}{|c|}{ Total }} \\
\hline & & \multirow{2}{*}{ Yes } & \multirow{2}{*}{ No } & \multirow{2}{*}{\begin{tabular}{|c|} 
Yes \\
$100 \%$
\end{tabular}} & \multirow{2}{*}{ No } & & \\
\hline 1 & Do you already experience the effect of Rice Tariffication Law? & & & & & 52 & $100 \%$ \\
\hline 2 & Is the effect of the said law being good to your livelihood? & 0 & 52 & $0 \%$ & $100 \%$ & 52 & $100 \%$ \\
\hline 3 & $\begin{array}{l}\text { Do you think the law helps in bringing down the price of milled } \\
\text { rice in the market? }\end{array}$ & 16 & 36 & $31 \%$ & $69 \%$ & 52 & $100 \%$ \\
\hline 4 & Do you still want to continue in farming rice? & 43 & 9 & $83 \%$ & $17 \%$ & 52 & $100 \%$ \\
\hline 5 & $\begin{array}{l}\text { Are the government programs under RCEF already reached } \\
\text { you? }\end{array}$ & 37 & 15 & $71 \%$ & $29 \%$ & 52 & $100 \%$ \\
\hline & $\begin{array}{l}\text { Free usage of rice farm types of machinery and equipment } \\
\text { given to eligible farmers association and registered rice } \\
\text { cooperative }\end{array}$ & 0 & 52 & $0 \%$ & $100 \%$ & 52 & $100 \%$ \\
\hline & Free certified inbred seeds & 48 & 4 & $92 \%$ & $8 \%$ & 52 & $100 \%$ \\
\hline & $\begin{array}{l}\text { Rice credit assistance with minimal interest rates \& minimum } \\
\text { collateral requirements }\end{array}$ & 32 & 20 & $62 \%$ & $38 \%$ & 52 & $100 \%$ \\
\hline & $\begin{array}{l}\text { Trainings for skills on rice crop production, modern rice } \\
\text { farming techniques, seed production, farm mechanization and } \\
\text { knowledge/technology transfer }\end{array}$ & 13 & 39 & $25 \%$ & $75 \%$ & 52 & $100 \%$ \\
\hline
\end{tabular}

Table 2 presents the impact of rice tariffication law to the respondents. According to the respondents, they already experience the initial effect of the law and $100 \%$ responded that it has a negative effect on their life because it drastically brought down the prices of palay. While the farm gate prices of palay are continuously declining, the prices of farm inputs that they are using are costly. Reduction in palay prices negatively affects the income of the farmers, most especially the small farmers. According to data from [7], the average palay production cost per kilogram in 2017 was Php. 12.42 and the average farmgate price of dry palay were Php18.21. With this cost and price, 
farmers earned a profit percentage of $46.62 \%$. If the farmgate price will decrease to Php. 12.44 per $\mathrm{kg}$ as projected by [8], the farmers must decrease their production cost to Php. 6.65 per kg to earn the same level of percentage profit. Though this profit margin is still too narrow to make economic sense to farmers.

Moreover, $69 \%$ of the respondents believed that the law is not helping in bringing down the prices of milled rice in the market. According to data from [9], this year's average retail price of rice from January to September 2019 was $\mathrm{P} 43.47$ per kilogram. This was lower by 2.5 percent from the previous year's level of $\mathbf{P} 44.58$ per kilogram. The monthly retail prices during the period were lower than their respective levels in 2018 except for the first three months of 2019 (Figure 1).

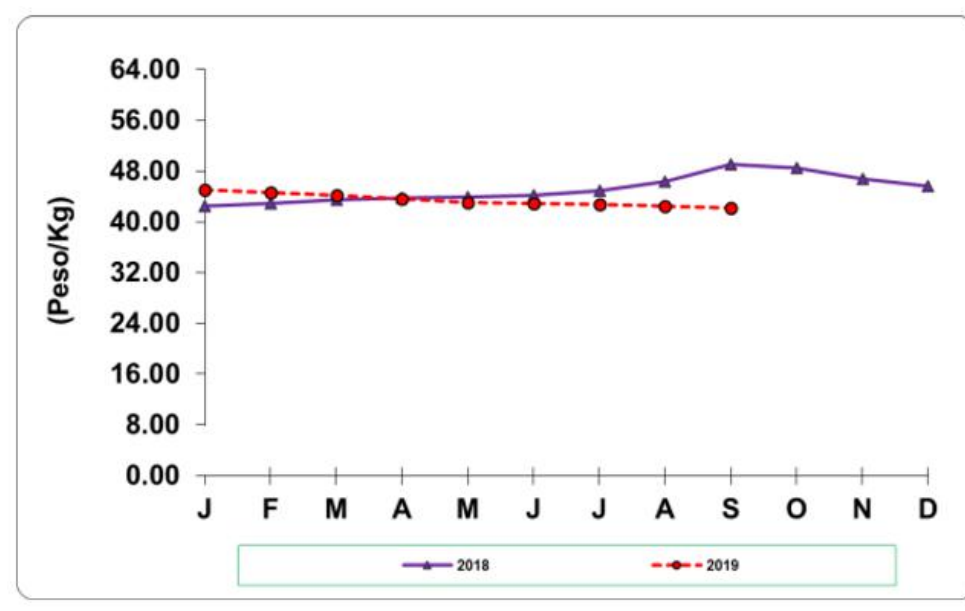

Monthly Retail Prices for Rice

Philippines, January 2018 - September 2019

Source: PSA

Figure 1

Despite the declining prices of palay, $83 \%$ of the farmers responded that they will continue to be rice farmers because this is the only way for them to earn a living for their family. The declining farmgate prices of palay can possibly affect the future decisions of farmers to continue on rice farming and if that happens there is a possibility that it will affect the supply of local rice in the country.
As to the implementation of safety net measures or the RCEF programs, rice farm types of machinery and equipment are not yet given to eligible farmers' association and registered rice cooperative. Meanwhile, $92 \%$ of the respondents already received free certified inbred seeds, $62 \%$ already availed rice credit assistance with minimal interest rate and $25 \%$ already attended trainings to enhance their skills and knowledge on rice production. 


\section{2019 Dry Season and Wet Season Farmgate prices of fresh palay}

Table 3. 2019 DS and WS Farmgate Prices of Fresh Palay

\begin{tabular}{|c|c|c|c|c|c|c|c|c|c|}
\hline \multicolumn{10}{|c|}{$\mathrm{T}$} \\
\hline Prices (Pesos) & 10.00 & 11.00 & 12.00 & 13.00 & 14.00 & 15.00 & 16.00 & 17.00 & 18.00 \\
\hline Frequency & & & 1 & 1 & 2 & 2 & 10 & 17 & 19 \\
\hline Percentage & $0 \%$ & $0 \%$ & $2 \%$ & $2 \%$ & $4 \%$ & $4 \%$ & $19 \%$ & $33 \%$ & $37 \%$ \\
\hline Total & \multicolumn{9}{|c|}{$52=100 \%$} \\
\hline \multicolumn{10}{|c|}{2019 WS Farmgate Prices for Fresh Palay } \\
\hline Prices (Pesos) & 10.00 & 11.00 & 12.00 & 13.00 & 14.00 & 15.00 & 16.00 & 17.00 & 18.00 \\
\hline Frequency & 2 & 4 & 30 & 10 & 4 & 0 & 2 & 0 & 0 \\
\hline Percentage & $4 \%$ & $8 \%$ & $58 \%$ & $19 \%$ & $8 \%$ & $0 \%$ & $4 \%$ & $0 \%$ & $0 \%$ \\
\hline Total & \multicolumn{9}{|c|}{$52=100 \%$} \\
\hline
\end{tabular}

Table 3 shows the 2019 DS and WS farmgate prices of fresh palay. Based on the gathered data during the 2019 DS, $37 \%$ of the respondents were able to sell their harvested palay at P18.00 and the lowest selling price was P12.00.

During the 2019 WS, $58 \%$ of the respondents were able to sell their harvested palay at P12.00 and the lowest selling price was $\mathrm{P} 10.00$
According to data of [9], the average farmgate price of palay from January to September 2019 was P18.27 per kilogram. This was 13.1 percent lower than the previous year's average price of $\mathrm{P} 21.02$. The monthly average farmgate prices per kilogram of palay showed a decreasing trend during the period, from P19.84 in January 2019 to P16.05 in September 2019 (Figure 2).

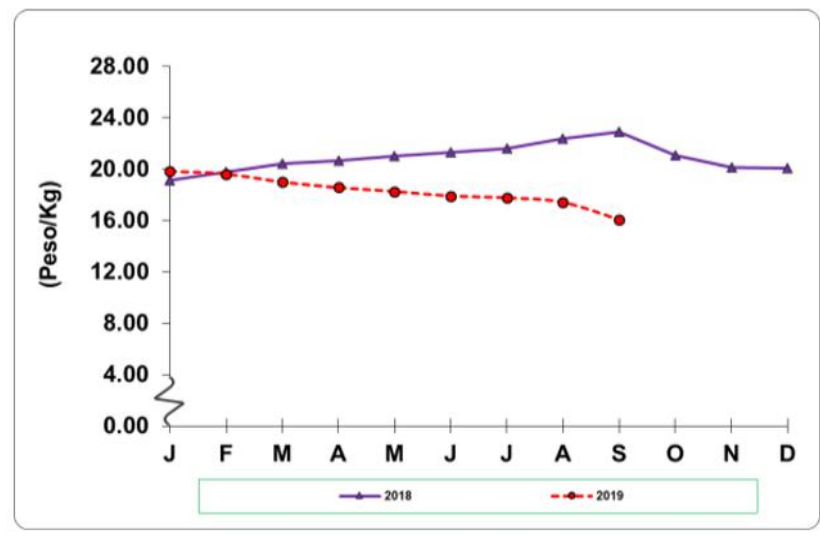

Monthly Farmgate Prices for Palay

Philippines, January 2018 - September 2019

Source: PSA

Figure 2

\section{CONCLUSIONS AND} RECOMMENDATIONS

Most of the respondents are familiar with rice tariffication law but they have little knowledge of how it works and how its implementation. According to them, they are not well-informed about the law and they only heard some information from other farmers and news from television and social media sites [10]. All of them responded that they are not in favor of the newly enacted law. The initial impact of the law was the declining farmgate prices of palay. Reduction in palay prices negatively affects the income of the farmers, especially the small farmers. Based on PSA data, it can be noted that there was a big difference in percentage change or reduction in 
the average farmgate price of palay and the average retail price of rice. The average farmgate price of palay was drastically declined while the average retail price of rice was hardly moved. Despite the declining prices of palay, they still want to continue in rice farming because this is the only way for them to earn a living for their family. The declining farmgate prices of palay can possibly affect the future decisions of farmers to continue on rice farming and if that happens there is a possibility that it will affect the supply of local rice in the country. Most of the respondents already received support from the RCEF programs of the government such as free certified inbred seeds, availed rice credit assistance with minimal interest rate and attended trainings to enhance their skills and knowledge on rice production.

It is recommended to encourage all farmers, especially the small farmers, to become a member of eligible farmer association or registered rice cooperative and to enlist to Registry System for Basic Sectors in Agriculture (RSBSA) for better access to information, agriculture-related programs and services of the government. In addition to the support from the government, rice farmers must consider diversifying their crops to improve their income. Likewise, they should be provided with the mostappropriate solutions which aimed to reduce their difficulties[11] in rice framing[12].Lastly, the government should provide the farmers with needed assistance and should undergo training to ensure their development [13] as cited in [14].

\section{REFERENCES}

[1] PhilRice, 2012. "Proceedings of the Policy Seminar on Philippine Rice Trade Policy and Rice Security: Future Directions" https://www.philrice.gov.ph/wpcontent/uploads/2014/09/Proceedings_TradeLibS eminar_2015.pdf Accessed: April 14, 2019

[2] Cororaton, C.B. 2004. "Can the poor benefit from the removal of QR on rice?" https://pidswebs.pids.gov.ph/CDN/PUBLICATIONS/pidsp n0404.pdfN Accessed: April 14, 2019

[3] Litonjua, A.C, Bordey, F.H., 2014. "How can rice trade liberalization affect producers and consumers?" Rice Science for Decision-Makers. Philippine Rice Research Institute
[4] F\&B Report Magazine, 2019. "The Rice Tariffication Law, explained" https://fnbreport.ph/features/agriculture/the-ricetariffication-law-explained-anrii-20190221/ accessed: April 14, 2019

[5] [5] House of Representatives. 2019. An Act liberalizing the importation, exportation, and trading of rice, lifting for the purpose the quantitative import restriction on rice, and for other purposes.

http://www.congress.gov.ph/legisdocs/ra_17/RA11203.pdf. Accessed: April 14, 2019

[6] Bordey, F., P. Moya, J. Beltran, C. Launio, D. Dawe. 2016. Can Philippine Rice Compete Globally? In Competitiveness of Philippine rice in Asia, edited by F. Bordey, P. Moya, J. Beltran, and D. Dawe. Nueva Ecija, Philippines: Philippine Rice Research Institute

[7] Philippine Statistics Authority. 2018. Selected Statistics on Agriculture 2018.

[8] Briones, R. and L. Tolin. 2015. Options for supporting rice farmers under a postQR regime: Review and assessment. PIDS Discussion Paper No. 2015-46. Makati City, Philippines: Philippine Institute for Development Studies.

[9] Philippine Statistics Authority. 2019. Palay and Corn Quarterly Bulletin. Volume 4. No. 1. July-September 2019.

[10] Subia, G. S., Mangiduyos, G. P., \& Turgano, J. B. D. (2020). Emergency Preparedness of Novo Ecijanos. Open Journal of $\begin{array}{lll}\text { Social } & \text { Sciences, } & \text { 17-23. }\end{array}$ https://doi.org/10.4236/jss.2020.83003

[11] Subia, G.S. (2018). Comprehensible Technique in Solving Consecutive Number Problems in Algebra. Journal of Applied Mathematics and Physics, 6,447-457. https://doi.org/10.4236/jamp.2018.63041

[12] Dilao, A., Asuncion, J. Eduardo, E., Dulay, C., Balaria, F.(2019). Status of Agricultural Food Sector: Basis for AProposed Continuity Plan.International Journal of Advanced Engineering, Management and Science (IJAEMS).Vol-5, Issue-7, https://dx.doi.org/10.22161/ijaems.578 ISSN: 2454-1311

[13] Zabala Jr., B., Gutierrez, M. and Subia, G. (2018) Needs Assessment of Barangay Tanawan, Dingalan, Aurora towards a Proposed Oplan Development Program. International Journal of Environment, Agriculture, and Biotechnology, 3, 2163-2167. https://doi.org/10.22161/ijeab/3.6.28 
[14] Mina, J.C., Barlis, P.T., Vega, N.C. and Subia, G.S. (2019) Corporate Social Responsibilities of Selected Resorts in Cabanatuan City, Nueva Ecija, Philippines. Open Access
Library
Journal,
6:
5292.

https://doi.org/10.4236/oalib.1105292 